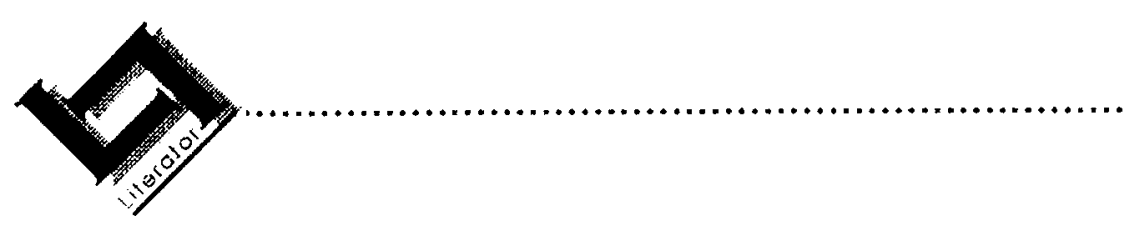

\title{
Afstand en vereenselwiging: Perspektiewe op die veranderende betekenisse van boer en Boer in die Afrikaanse poësie
}

\author{
Dorothea van $\mathrm{Zyl}$ \\ Departement Afrikaans en Nederlands \\ Universiteit van Stellenbosch \\ STELLENBOSCH \\ E-pos: dpvz@maties.sun.ac.za
}

Astract

Distance and identification: Perspectives on the changing connotations of boer and Boer in Afrikaans poetry

A comparison of various lemmas on boer/Boer in a number of dictionaries, as well as research on the application of these terms in a variety of poetic (and other) texts written during the 19th and 20th century, reveals interesting similarities and dissimilarities regarding both the definition and the utilization of the terms in Afrikaans and Dutch texts. In Afrikaans and in Afrikaans poetry, where Boer (and sometimes boer, under influence of the values attributed to Boer) is often used as an ethnonym, different meanings of the term correspond with the historical, sociological and ideological context. Alternatively, both terms are employed negatively, suggesting a perspective of distance, and positively, implying proximity and identification. The option selected depends on the specific intent and the context, but the terms are often used ambiguously, reflecting a multiplicity of meaning(s)

\section{Inleiding}

Volgens Edward Said (1978:21) word nie waarheid nie, maar representasie gesirkuleer deur "cultural discourse and exchange within a culture". Ons leer die verlede slegs ken deur sy tekste en dié is onafwendbaar getekstualiseer, geïnterpreteer, fiktief en tydgebonde. Hierdie idees, wat saamhang met eietydse denkrigtings oor die aard van die geskiedenis, asook met die koloniale en postkoloniale diskoers, geld uiteraard nie alleen vir prosatekste nie, maar ook vir poësie. Nadat literatuurteoretici in 
sowel die negentiende as die twintigste eeu klem gelê het op die outonome en a-historiese aard van veral die poësie, staan die kardinale rol wat die maatskaplik-ideologiese konteks speel by die literêre produksie van enige aard die afgelope dekades sterk in die belangstelling.

Die konteks bepaal onder andere die seleksie van bepaalde woorde en terme (die inventio), sodat ook vir die poësie die volgende uitspraak van Engbersen en Jansen (1991:14) geld:

Het vinden van een geschikt woord waarmee een situatie, zaak of persoon wordt aangeduid, is bijzonder belangrijk. Een woord is namelijk niet alleen een woord, maar ook een drager van potentiële argumenten. Het introduceren van een woord is het binnensmokkelen van een argumentatieketen.

Hierdie argumentasieketting, of ander eenhede in die uitbeelding wat tot stand kom, hang op sy beurt onafwendbaar saam met 'n ideologiese geladenheid van die een of ander aard, gekoppel aan 'n sosiaal-politieke konteks.

In hierdie artikel wil ek veral die betekenisverskuiwings nagaan wat die begrippe boer en Boer sedert die negentiende eeu ondergaan het binne Afrikaanse poësietekste, met 'n (vlugtige) uitwysing na die ruimer konteks van relevante Nederlandse, Engelse en ander geskrifte. Die pad wat 'n woord soos dié binne die geskiedenis geloop het, open interessante perspektiewe op die verband tussen literatuur en werklikheid/ maatskappy, onder meer met betrekking tot die veranderlikheid van aspekte soos persepsie, representasie en konvensie. Dié artikel, 'n literêre eerder as 'n leksikologiese ondersoek, fokus spesifiek op die begrippe boerl Boer, en die veranderende karakteriserende konnotasies en assosiasies wat dit in die literatuur opgeroep het. Hierby word woordeboekbetekenisse, wat uiteraard eweneens tydsgebonde en verskuiwend van aard is, aanvanklik as vertrekpunt geneem. Weens die groot tydspan gedek en die omvang van die onderwerp kan 'n kort artikel soos hierdie hoofsaaklik 'n eerste aanset wees, 'n breë oorsig waarin sekere tendense tentatief aangedui word, maar sonder aansprake op volledigheid.

\section{Die betekenis van boer en Boer in woordeboeke en enkele ander geskrifte}

Verskillende betekenisse, met verskillende herkomste wat getuig van sowel neutrale as positiewe en negatiewe houdings, val saam in die woord boer. Volgens Van Dale Etymologisch Woordenboek (1989) beteken "boer': [landbouwer] middelnl. geboer, gebuur [medebewoner, buurman, dorpeling, boer], in de $16 \mathrm{e}$ eeuw ook boerman [boer]". Die 
betekenis van boer ${ }^{2}$ is: "[oprisping] waarschijnlijk klanknabootsing". Verder word boerde (uit die Frans) geassosieer met "klucht, "bedrieglijke grap, zotternij" en "plezier". Volgens die Middelnederlandsch Handwoordenboek (1976) beteken gebuur (medewoner) enersyds "een vriendelijk, hulpvaardig mensch; een goede kennis, vriend" en andersyds "een lastig mensch, vijand; wederpartij". Daarnaas staan gebuur (2) vir: "medeburger, burger, ingezetene" en (3) "plattelandsbewoner, dorpeling, boer", terwyl boer ook dui op: "Een standje, getier om iem. uit te jouwen, het plegen van verzet", in aansluiting by bore (ook buere, buer): "Twist, gevecht".

In die eietydse Nederlandse woordeboek, Van Dale (1984), word die volgende relevante betekenisse met boer verbind: (1) landbou, (2) platteland, (3) "lomperd, ongemanierd persoon", en (4) "(met hoofdl.) Hollands sprekende kolonist van Zuid-Afrika". Die woord boer beteken in Nederlands ook steeds "hoorbare lozing van gassen uit de maag". Daarnaas kom boerachtig voor en sy sinoniem boers, asook by die werkwoord boeren onder meer "rumoer maken, drinken en klinken, losbandig leven; (ook) knoeien". Heelwat meer samestellings met boer is negatief in Nederlands as in Afrikaans - 'n aanduiding van die mate waarin die twee tale verskillende rigtings ingeslaan het met hierdie woord(e)

Hierdie verskille blyk veral uit die talle bladsye (465-469) verklarings van en kombinasies met boer/Boer in die Woordeboek van die Afrikaanse Taal (1950), waarby positiewe betekenisse oorheers. Dié uitgawe uit 1950 , kort na die Nasionale Party se oorwinning in 1948, se plasing en uiteensetting van die begrippe lyk vanuit 'n hedendaagse perspektief ideologies gelaai: die betekenis van Boer as "Benaming van ' $n$ lid v/d Afrikanervolk; vroeër veral gesê van Afrikaners v/d gewese republieke in S.A." word eerste geplaas (by Van Dale vierde). Die lemma boer (kleinletter) word verbind met slegs (1) die landbou, (2) platteland, (3) "(i/d mv.) Kêrels, maats", (4) kaartspel en (5) skaakspel. Betekenis (3) van Van Dale, wat van afstand getuig in die perspektief, word vervang met "Kêrels, maats", wat op gemeensaamheid dui. By boeragtig kom wel 'n betekenisaanduiding voor wat ooreenstem met boers: "Soos 'n boer [dikw. geringskattend]; ongemanierd, grof" en by Boer(e)-, boer(e)- as eerste deel van 'n samestelling staan wel ook: "... soms $\mathrm{m} / \mathrm{d}$ bygedagte van ru, ietwat primitief en geïmproviseer (...), maar dit word gekombineer met "ook dikw. m/d bygedagte dat so 'n (noodhulp)-artikel besonder sterk, duursaam en prakties is".

Die meeste beknopte Engelse woordeboeke, soos die The Concise Oxford Dictionary uit dieselfde dekade (1944) onderskei tussen Boer: "(Of) Dutch or Dutch-descended S.-African(s)" en boor. "Peasant, clumsy 
or ill-bred fellow" (soos Van Dale 3). Kyk ook Webster's New International Dictionary (1948), New Collegiate Dictionary (1979), Longman Dictionary of Contemporary English (1990) en Cambridge International Dictionary of English (1996). In Collins Cobuild English Language Dictionary (1990) word boor bestempel as "an old-fashioned word".

Volgens die uitgebreide Oxford English Dictionary (1989) is boor "(a) word of involved history" wat stam van búr ("dweller"), wat ook "dwelling" (blyplek) beteken. Aanhalings uit Oud-Engelse bronne (1430 en 1551) toon dat boor (of vorme daarvan) aanvanklik redelik neutraal gebruik is. Die eerste teksaanhalings waarin 'n negatiewe konnotasie aan boor geheg word, dateer uit 1598. Boer se betekenis word aangegee as: "Countryman, peasant farmer, the same word that in a general sense is spelt Boor. The latter was formerly used also for the Dutch settlers in South Africa, but in more recent times the Du. spelling boer has been appropriated to this sense". Boer word vervolgens aangedui as: "Dutch colonist in SA", met positiewe voorbeelde, soos Livingstone se verduideliking in 1857: "the word Boer simply means 'farmer', and is not synonymous with our word boor'. Uit 1887 dateer 'n uitspraak dat Boer "in recent newspaper language" gebruik word vir inwoners van die Transvaal en andere buite die Britse gebiede. Sowel die omskrywing as die voorbeelde toon dat die etnoniem Boer (hoofletter) waarskynlik Brits van oorsprong is. (Etnoniem is ' $n$ term uit die etnisiteitstudie, vir "names referring to groups either linguistically or geographically" - Grünthal 1997. Dit dui op mense wat 'n gegewe etniese merker deel, naamlik: "an objective ascriptive property such as language, religion, or race, that can be used to characterize members of a minority group" - Riggs, 1999.)

Die betekenisse wat boer en Boer binne die Suid-Afrikaanse konteks bygekry het, word aangedui in A Dictionary of South African English (1980), met die uiteensetting dat die voorvoegsel Boer (hoofletter) 'n "national or political significance" het. Daar word egter nie deurgaans 'n duidelike onderskeid tussen hoof- en kleinletters gehandhaaf nie. Boor ontbreek as aparte inskrywing, maar word wel as sinoniem met Boer gebruik in sommige van die voorbeelde. Naas: "An Afrikaner ... often in a political sense" (betekenis 1), die gebruiklike betekenisse van "early Dutch colonist" (2), "farmer" (3) en "a Republican fighter in either of the Boer Wars" (4) figureer ook boer: "slang; a prison warder or policeman" (5), "Black Border Usage. A member of the S. Afr. Forces" (6) en "Urban Afr. An African term of abuse for someone of mixed blood" (7). Ampie Coetzee (1999:9-10) sluit by hierdie pejoratiewe etnonieme aan. Hy assosieer boer eerstens met "takhaar, plaasjapie, ongekultiveer" (vergelykbaar met Van Dale se 3de betekenis, die Engelse boor en met boers) en sê vervolgens oor Boer (hoofletter): "Sedert die institusio- 
nalisering van apartheid deur 'n Afrikaner-regering het boer Boer geword en ' $n$ besliste ideologiese verbintenis gekry met polisie, weermag, mag".

Dit blyk uit die verskillende woordeboeke dat boer/Boer van vroeg af geen eenvoudige begrip was met ' $n$ enkelbetekenis nie. Teenstrydige en selfs teenoorgestelde betekenisse word met dieselfde woord geassosieer (anders as by farmer). Die seleksie van ' $n$ bepaalde betekenis van boer, wat ook verband kan hou met die keuse vir 'n hoof- of kleinletter, hang dus noodwendig saam met die keuse vir die oproep van 'n gepaardgaande konteks. Afhangende van die keuse vir 'n positiewe of ' $n$ negatiewe konnotasie impliseer die woord op sigself reeds óf afstand óf vereenselwiging indien ' $n$ perspektief ('n kyker) daarby veronderstel word.

\section{Boer en boer in die lefterkunde en enkele ander geskrifte}

Van Dale se vier relevante onderskeidings, aangevul deur die omskrywings van A Dictionary of South African English (1980), word vervolgens gebruik om die stof te sistematiseer. Hierby word veral gelet op die manier waarop dieselfde woord binne verskillende tekste en kontekste 'n neutrale, positiewe of negatiewe optiek oplewer, vereenselwiging of afstand. Oorvleuelings van die kategorieë kom ook voor, omdat die poësie juis graag dubbelsinnighede uitbuit.

Dit is byvoorbeeld opvallend hoe die verskillende karakteriserende betekenisse gekoppel aan die begrip boer (uiteraard nie die term nie) en sy bedryf mekaar van vroeg af aanvul binne die letterkunde. In die Georgica (in Blanckenberg, 1975) van Vergilius (47 v.C.),'n lang leerdig oor die boer en boerderybedrywighede, is daar oorwegend sprake van vereenselwiging, soos by Van Dale (betekenis 1). Wanneer die Bacchusfeeste in die afdeling oor wynboerdery egter verbind word met die digkuns, "ou tonele in teaters", danse en "geestigheid" loer die boertige assosiasie (Van Dale betekenis 3) wat van groter afstand getuig, egter om die hoekie: in 'n vergelyking met die Atheners "(...) vermaak Italiaanse boere, ' $n$ volk van Troje af gestuur, vir hul/ op ruwe verse en uitgelate grappe", met maskers en "vrolike gesange" (in Blanckenberg, 1975:107-108). Vergilius kontrasteer die boerelewe met sy "milde leeftog" verder met dié van rykes met "fiere wonings", "wit wol bevlek met gifstof" en olyfolie "met kaneel besoedel". Die boere se "rus is sonder sorge, hul lewe opreg en ryk" (Blanckenberg, 1975:111). Die kontras stad en platteland spreek reeds implisiet hieruit, met voorkeur vir die landelike of plattelandse (Van Dale-betekenis 2). (Daar moet wel in gedagte gehou word dat ook die vertaler se optiek 'n rol kon gespeel het.) 


\subsection{Landbouer}

In die Middeleeuse liriek en (ridder)epiek, is verwysings na boer (in enige betekenis, asook sinonieme) skaars, waarskynlik vanweë hulle beskeie maatskaplike posisie binne die Middeleeuse standemaatskappy. Die optiek wissel oor die algemeen van neutraal tot negatief. Die dorpers wat in die diere-epos Van den vos Reynaerde (12de-13de eeu) stryd voer teen die diere, is enigsins vergelykbaar met boere. In "Van de kerels" (14de eeu - in Antonissen, 1986:99) dui kere/s (sterk pejoratief gebruik) op die ruwe, onbeskaafde boere en Anthonis de Roovere (ca. 14301482) plaas in sy bekende "Vander Mollenfeeste" (in Van Vliet, 1998: 203-206) Pachters ende Rentenieren (wat die naaste aan boere kom) ook maar laag op die sosiale leer.

Vanaf die 17de eeu raak verwysings na boere meer algemeen. In hofdigte soos Het lusthof Rynneveen (ca. 1715) deur Willem van Hoeven, Westermeer (1721) van Frans Ryk, asook in Elzenburg (1721) deur Peter Verhoek en Hendrik Schim se Havezicht word die arbeidsvreugde van boerewerkers geïdealiseer (W. de Vries, 1998:33), dikwels in kombinasie met woorde wat saamhang met Van Dale se betekenisse 2 en 3. Die term boeren word meermale vervang deur meer "verhewe" woorde soos lantman of herdersjongen, in aansluiting by die tydvak en die genre.

Van die eerste Suid-Afrikaanse verwysings na boere, in Teenstra se Zamenspraak of uittreksel van een door mij gehouden gesprek met een' boer, deszelfs vrouw en hunne slaven, te Caledon, kolonie Kaap de Goede Hoop uit 1825, is redelik neutraal (Nienaber, 1942:2-6). Oor die algemeen is positiewe verwysings na boer wat van vereenselwiging spreek, in Afrikaans egter relatief talryker as in Nederlands. Dit blyk reeds uit die hoofsaaklik 19de-eeuse gedigte in Afrikaanse Gedigte, Byeenfersameld uit wat in di laaste 30 jaar ferskyn is 1876-1906 (faksimilee 1987), waarvan S.J. du Toit waarskynlik die samesteller was (Kannemeyer, 1978:56), soos "Afrika's Klagte" (1987:3): "Waar di boer syn moeite ryk beloon word", en verder in poësie deur digters soos G.A. Watermeyer (1948), Blum (1955), Boerneef, Riekert, en ander.

Die neutrale/positiewe term boer, vir landbouer, word uiteraard steeds gebruik binne sowel die Nederlandse as die Suid-Afrikaanse poësie. Omdat dit redelik voor die hand liggend is, word nie verder daarop ingegaan nie, behalwe vir die volgende klein steekproef: hoewel Breytenbach boer in sy latere poësie soms pejoratief gebruik, kom die woord in sy neutrale betekenis steeds meermale in sy poësie voor (kyk Coetzee 1995:46, 107, 108, 116, 236, 315). In die eietydse Nederlandse (insluitend die Vlaamse) letterkunde bestaan daar die afgelope dekades wel opvallend min belangstelling in boere en hul bedrywighede. Jans- 
sens $(1994: 163,175)$ wys daarop dat "de mythisering van de Vlaamse Boer (met hoofdletter)" gevolg is deur "de grondige problematisering van de materie in de overigens schaarse teksten van niveau die na de Tweede Wereldoorlog nog aan het landelijke leven in Vlaanderen gewijd werden". Weens die verstedeliking en "gesofisticeerd technologisch arsenaal" vorm die boere 'n steeds kleiner persentasie van die bevolking - in 2000 in België nog maar 2 persent - sodat "de boer op dit ogenblik veel van zijn potentieel aan romantiek ingeleverd (heeft)". Hugo Claus se poësie speel wel meermale in op die landelike, die boeremilieu en die Vlaamse landskap. Soms word redelik neutraal na boere verwys, soos in Voor Charlotte (Claus, 1994:72: "De boer weet hoe laat het is ..."), maar soms het boer by Claus 'n negatiewe lading (dit kom later ter sprake). Rutger Kopland roep meermale die landelike in sy gedigte op, maar spesifieke verwysings na boer is skaars. Dit kom wel voor in gedigte soos "Pastorale" (1966) en in "Boven het hooi hangt de boer ..." (1975) (Kopland 2000:22, 141). Jan Hanlo se "De meiden meehelpen het weidevee melken" ("'t Boerenleven lijden (...) Doet de geest en 't lichaam sterken/ 't is goed om flink te werken") uit 1970 herinner aan W.E.G. Louw se ekstatiese "O om 'n boer te wees wat werk ..." (1931/1961:22).

Negatiewe perspektiewe wat van meer afstand getuig, waarby geteken word hoe boere die perke van die konvensionele verwagtinge oorskry, kom in Afrikaans veral sedert die vyftiger- en sestigerjare voor. In "Nuusberigte 1956" (1962) praat N.P. van Wyk Louw van "boere wat vandag in die stad boer" (1963:114) en W.E.G. Louw (1988:175) hekel die boere soos volg in "Geloftedag, 1967": "Ryk Vrystaatse boere sit en wag/ al op die sonnige terras/ ongeduldig vir die kroeg om oop te gaan". Ook Sheila Cussons (1978) wys in "Die boer is nou moderne boer" (Komrij, 1999:548) op die verskille met die verlede. In "ons dorp XIII": "maandae kom die boere dorp toe ..." (Krog, 1985:33) gee Antjie Krog 'n humoristiese tekening van boerebedrywighede wat drasties afwyk van die vereenselwigende blik van die verlede. M.M. Walters, die vernaamste eksponent van die satire in Afrikaans, rig hom reeds sedert 1967 meermale teen die boere, soos in "Boeremaaltyd" (Walters, 1967:59): "O boereplaas, geboortegrond, / hoe smelt die vetskaap in my mond!" In Heimdall (Walters, 1974:11, 14, 29, 31) sit hy sy satiriese aanslag voort in gedigte soos "Die arme boer", "Die boer is in die Strand" ("... baasskap koelte lang siëstas"), "So ry die boere" ("sal ek jou finaal laat voel/ wie baas is") en "Trekboer", asook in "Apocrypha LIV": Boere: "Ons praat nie nou oor wingerd/ of oor wyn nie,/ maar van reise oor die see" (Walters, 1986:93).

Hierdie tekste, waar humor, satire en geestigheid afstand tussen die kyker en sy objek skep, hou ook verband met die ontmitologisering van 
die boer en Boer wat op die nasionalisties-gedrewe verheerliking van vroeër gevolg het. Dit was egter nie beperk tot Suid-Afrika nie, soos blyk uit die volgende afdeling:

\subsection{Platteland (teenoor stad)}

Die positiewe assosiasie van boer met die landelike en plattelandse, dikwels in kontras met die (negatiewe) stedelike, is van vroegs af algemeen, onder meer in die wyd-verspreide pastorale poësie vanaf die Hellenisme tot die Renaissance, Barok en Rococo (kyk Van Gorp, 1993: 297). Positief soos Vergilius se Georgica en ook uit die eerste eeu v.C, maar met 'n totaal ander inslag, is die gedig "Beatus ille" van Horatius. Daarin het hy volgens W. de Vries (1998:33) "het beeld van de gelukkige landman geijkt, en in de Renaissance heeft men in heel West-Europa daarop voortgeborduurd". In die groot aantal hofdigte wat in die 17de en 18de eeue in Nederland verskyn het, skets die digter "het beeld van een landheer op zijn buitengoed, die ver verwijderd is van het morele verderf dat in de stad heerst". Die kontras tussen stad en 'n idilliese platteland word onder andere deur Huygens (1596-1687) besing in sy Hofwijck (1653) en in De Moufe-schans (1621) praat Petrus Honius herhaaldelik kontrasterend van "Ramp der steden" (De Vries, 1998:32).

Janssens (1994:163-178) en Vaartjes (1998) karteer die ontwikkelinge van die Vlaamse en Nederlandse streek- of landelike roman, wat ook lig werp op die breë konteks ten opsigte van die poësie. Hierdie idealiserende, Arkadiese, "patriarchale Vlaamse bucolica" (Janssens, 1994:166) het tydens die nabloei van die Romantiek ontstaan, met Hendrik Conscience as hooffiguur. Trekke daarvan is vergelykbaar met die Afrikaanse plaasroman deur Malherbe, Van den Heever, en andere, maar meer ooreenkomste kan uitgewys word met die tweede golf naturalisties-getinte romans van rondom 1900 deur veral Stijn Streuvels. Ook Cyriel Buysse, Ernest Claes, Felix Timmermans, Karel van de Woestijne en Herman Teirlinck is eksponente van die tipe narratief met sy dikwels mitiese dimensie (Janssens, 1994:173), wat ook baie populêr in onder meer Skandinawië en Nederland was. 'n Toppunt is in die twintiger- en dertigerjare bereik, toe die Nobelprys drie keer aan eksponente van dié genre toegeken is (1920, 1924 en 1939 - Vaartjes, 1998:43.)

In Nederland en elders is die klimaat vir die stroom streekliteratuur na die Eerste Wêreldoorlog geskep deur sowel die denkrigtings van Henri David Thoreau (1817-1862) as dié van Leo Tolstoi, wat wou terugkeer na die natuur. Tolstoi het die boerebestaan met sy inherente primitiewe goedheid verheerlik (vgl. Van Zyl, 1995:125). Vroeër het Van Eeden en Verwey hierdie tipe idees ook met Suid-Afrika verbind: "De Zuid- 
Afrikaanse Boeren staan in dit verband model voor natuurlijke eenvoud" (Van Halsema, 1994a:26). Die Anglo-Boere-oorlog het vir hulle "het ideale projectiescherm" gebied vir hulle "eigen ideologische preoccupaties" (Van Halsema, 1994b:382-383) - nog 'n illustrasie van die kruisbestuiwing in gedagtegoed met betrekking tot boer en Boer.

Anders as in die Nederlande en Skandinawië, het die poësie oor die mite van die boer en sy grond in die dertigerjare van die vorige eeu regse politieke konnotasies gekry in lande soos Joego-Slavië, die Sowjet-unie, Kroasië, Hongarye, Pole en veral Oostenryk en Duitsland. In NasionaalSosialistiese Duitsland is dit byvoorbeeld gebruik om die besef aan te wakker van ras, geboorteland en "Germaanse wortels" (kyk Althof, in Bakker, 1994:1105-1107). Die Nasionaal-Sosialistiese bevordering van Heimat-romans, op grond van die Blut und Boden-beginsel, het die streekroman se bona fides onder verdenking gebring. Nederlandse streekromans deur Herman de Man en Antoon Coolen het nogtans groot aanhang in talle lande geniet, maar nie by die literatore nie (Vaartjes, 1998:43). Die Afrikaanse plaasromans van veral Van den Heever was in dié sin produkte van hul tyd deurdat die outeur sterk beïnvloed is deur die idees in Oswald Spengler se Der Untergang des Abendlandes (19181922), soos blyk uit sy uitspraak: "... het Spengler nie vir ons die waarde van hierdie bodemvaste kultuurdraers (die landelike mense in kontras met 'sekere stadstipes' - DvZ) beklemtoon nie?" (Van den Heever, 1934:13; kyk ook Timmermans, 1996:27). Coetzee (1999:93) neem hierdie ruimer filosofies-ideologiese konteks miskien nie genoegsaam in ag by uitsprake soos die volgende oor die Afrikaanse plaasroman nie: "Vir die plaasbewoner, vir die boer, vir die Afrikaner moes 'n persepsie geskep word van die stad as verwerplik". Dit was idees wat veel wyer aangehang is as slegs in Suid-Afrika.

Die kontras platteland (positief) teenoor stad (negatief) geld volgens $A$. de Vries (1998:34-35) steeds in die Nederlandse jeugliteratuur, soos in Willem Wilmink se Ver van die stad (1977). Ook in die poësie van 'n Nederlandse digter soos H.H. ter Balkt of Habakuk II de Balker (pseudoniem van Foel Aos) "... worden het boerenbestaan en de natuur tegenover de bedreiging door de moderne mens getekend ...". In bundels soos Boerengedichten/Uier van 't oosten (De Balker, 1974) ontgin hy elemente van die (dikwels vergange) plaaslewe op 'n woordryke, ironiese en byna Barokagtige wyse, wat soms aan Lucebert se poësie herinner.

In Afrikaans kom hierdie kontras, vooruitlopende op en in aansluiting by die plaasromans, in heelwat Afrikaanse poësietekste voor. Trekkerswee (1915) van Totius was byvoorbeeld een van die vroegste tekste wat die probleem van die grootstad aan die orde stel. In "Ballade van die 
Grysland" (1947) bou D.J. Opperman hierop voort, met verwysing na die volgende reëls uit Trekkerswee: "Die vroegre boere-paradijs/ is nou éen molshoop, groot en grijs" (Opperman, 1967:13). Dieselfde reëls sou J.C. Steyn (1975:38) later sterk ontluister in sy gedig: "Die vroegre Boereparadys". "Boer" word in 'n gelyknamige gedig in Heilige Beeste (1945), ' $n$ bundel wat die stad in etlike gedigte met negatiewe assosiasies verbind, gekombineer met die arbeidsetos, die boer wat agter die ploeg stap om mielies te verbou "... waaruit/ fabriek en stad en/ nasie spruit" (Opperman, 1947:14). Naas in Boerneef se werk waar die "spanning tussen stad en land ... 'n bestendige tema (...) sou bly" (Botha, in Pienaar, 1968:311) word hierdie kontras ook nog aangetref in "god boer" van Breytenbach (1967:58) en in Marlene van Niekerk (1977:16) se "die een se kultuur is die ander se koring", waar afstand blyk teenoor die Bolandse "kulturele groep" en intellektueles, teenoor vereenselwiging met die "boer" in die "godverlate binneland".

Ander tipe kontraste, maar steeds vereenselwigend met die boer en gekombineer met 'n nogal pejoratiewe perspektief op die Ander, kom voor in die doelbewus teenstrydige reekse wat W.E.G. Louw gebruik in "Somerreis" (1972): "... kruier, dogter, boer,/ dié outa wat so koulikrig sy rietjies roer ..." en in "Mure" (Louw, 1988:223): "... eienaar - dief,/ die boer - die Boesman en die bobbejaan". Hierteenoor stel Breytenbach (in Skryt, 1976) die kontras stad, of eerder township/plaas in 'n totaal ander lig. Hy plaas aanvanklik die kinders van "Dimbaza,/ van Welcome Valley, Limehill en Stinkwater" teenoor "die gebied van die boer" en praat vervolgens van "die Boer en sy God", "die aarde van die Boer" en "die land van die Boer" (Breytenbach, 1976:22). Hier word die betekenis van die land en landelike dus pertinent gekoppel aan Afrikaners.

Met betrekking tot die "Vlaamse boerenfolklore" wys Janssens (1994: 171) op die wrang ontmitologisering en demistifisering in Hugo Claus se sarkastiese "Suite flamande", veral in "het parlando-gedicht 'De boeren', asook in "Zuid-Oost Vlaanderen", in sy bundel Almanak (1982). In die prosa getuig veral Leo Pleysier se verhale van vervreemding en ontheemding van die boeremilieu (Janssens, 1994:177). Bert Popelier se gedig "Vlaamse Pastorale" is 'n obsene ontluistering van die tradisionele beeld van die boerelewe, terwyl ook "nostalgisch retrosentiment" 'n rol speel in Wim de Craene se lied "Tim". Volgens Janssens (1994:178) blyk die tradisionele landman se ploeg tans "echt in een diepe voor (..) vastgelopen te zijn".

Hierdie ontmitologisering sluit aan by dieselfde tendens in 'n hele reeks plaasromans sedert Leroux se Sewe dae by die Silbersteins (1962), waarin kwessies van grond, landskap en plek weer sterk in die kalklig geplaas word - kyk Van Coller (1995:26) en Wasserman se nuansering 
(1997:90-94) dat dit eerder gaan om 'n wisselende afstand en vereenselwiging.

\section{3 "Lomperd" - pejoratief}

Hierdie spottende betekenis van boer, wat geassosieer kan word met boers, takhaar, is veel meer algemeen in Nederlands as in Afrikaans. Bredero, die bekende 17 de-eeuse digter wat etlike kere na boeren verwys in sy Boertigh, Amoreus en Aendachtig Groot Lied-boeck (1622), sy klugte en toneelspele, gebruik boer veral in hierdie derde betekenis van Van Dale. Ook in sommige van die $17 \mathrm{de}$ - en 18de-eeuse hofdigte word die seksuele aspek, grofheid en afkeer van die stad by die boere uitgelig. Boere is, in die woorde van Philibert van Borsselen in De Binkhorst (1613): "Van seden bot maer vry, van leden grof maer vaerdigh". W. de Vries (1998:32-33) wys daarop dat die realiteitswaarde van hierdie perspektief dubieus is, "omdat literaire conventies (...) hier een belangrijke rol spelen". Met hierdie konvensies speel ook Paul van Ostaijen in sy "Boere-charleston" (1929, in Borgers, 1974:217). In Hugo Claus se "Pastorale" (Claus, 1982:12/6) word verder geestig die spot gedryf met die spanning tussen die boer se seksbelustheid en sy pligsgevoel, terwyl "de boeren (Claus, 1979:128) 'n beeld skep van bygeloof en agterlikheid: "'s Zondags, na de mis, schuiven zij,/ geschoren, in overhemd, vervormd, onwennig, over hun akkers". Die uitroep "lompe boer" (Claus, 1982:29/10), die naaste aan dié woordeboekbetekenis, het selfs niks meer met 'n boerdery te doen nie, maar is bloot pejoratief.

As (ligte) pejoratief kom boer enkele kere voor in komiese Afrikaanse gedigte uit die 19de eeu, soos "Op Hartebeesfontyn" van Pikkedel (in Afrikaanse Gedigte 1876-1906; Anon., 1987:111-112) en sy pendant "was jy perduks eens op ' $n$ tyd/ al op 'n regte boerjolyt/ daar by De Poort se stasie" deur Pieter Grobbelaar (in Hugo, 1988:45-46). In "Die prokureur sij (sic) hond" (in Reitz, [1909]1916.99) dink die "domme Boer" (hier met 'n hoofletter) verkeerdelik hy kan 'n prokureur uitoorlê. Hierdie ietwat neerbuigende tipe perspektief was kennelik nie ongebruiklik binne die samelewing nie, soos blyk uit die hekeling met Engelse skole en meisies wat afwyk van die "ouwe sede" in "Fooruitgang" deur Jan wat versiis maak (in: Afrikaanse Gedigte 1876-1906; Anon., 1987:13-14): "... boer is tog so 'n lage naam!/ En 'n boer het harde hande en draag groffe klere ook".

Die negatiewe, selfs pejoratiewe assosiasies met boer en boor in veral die 19de eeu het ' $n$ afstand in perspektief geskep, waarby die boer inderwaarheid in die posisie van die Ander geplaas is. Veral in die opbou tot 1948 en daarna is die Afrikaanse assosiasies met boer egter, soos 
blyk uit die reeds aangehaalde omskrywings in die Woordeboek van die Afrikaanse Taal (1950), doelbewus weggestuur van dié algemene Nederlandse betekenis vanweë die sosio-politieke konteks, die opbou in nasionalistiese gevoelens voor en nadat die Nasionale Party in 1948 aan bewind gekom het. Dit het gevolglik gebruikliker geword om boer in SuidAfrika pejoratief te verbind met mag, gestel teenoor ander landsbewoners oor die kleurgrens heen, as met 'n posisie van ondergeskikte.

Die eerste sprake van 'n negatiewe lading, en afstand met betrekking tot boer ná die Anglo-Boereoorlog, word opvallend genoeg reeds binne die konteks van die rassekwessie geplaas, hoewel nog baie tentatief in vraagvorm. Dit kom voor in Leipoldt se "In ou Booi se pondok" (1911), waar onder meer gevra word: "Het die boere toe die swartvolk,/ soos ' $n$ boerplaas maar verpag?" (Leipoldt, 1921:23). Die res van dié lang, wydlopige gedig in hierdie "indrukwekkendste enkele bundel van die Tweede Afrikaanse Beweging" (Kannemeyer, 1978:132) klink weliswaar pejoratief met betrekking tot die "Boesman" se voorkoms en oorwegend positief teenoor die voorsate, maar spreek tog van skuldgevoelens oor en negatiwiteit teenoor die mishandeling van die slawe en die uitsterf van die Boesmans.

Hierna is in Afrikaans veral weer sprake van afstand in die vyftigerjare, in P.J. Philander se debuutbundel Uurglas van 1955 - ook binne die konteks van die spannings tussen bevolkingsgroepe. In die agste strofe van "Reliëf" word verwys na die "boere" wat in die winter nog altyd laer trek, "terwyl 'n verflenterde volk/ (...)/ 'n leeftyd al verslaaf/ is aan pik en graaf" (1956'35-36) - kyk ook die volgende afdeling oor Boer. 'n Teenoorgestelde perspektief bied die woordgebruik van Peter Blum "Nuus uit die binneland" (1955): “... weet ons op watter vasteland ons boer" (Blum, 1963:10), waar die Kaapse "beskawing" gestel word teenoor die "droogte en brand, en gerug/ van sprinkaan, aardbewing en oproer" van Afrika. Etienne van Heerden (1987:82) se gebruik van "ons" in "Laaste loopgraaf' spreek van 'n nog groter ironiese "vereenselwiging" met diegene wat weier om Afrika, "hierdie onmooi nooi" lief te hê: "hier rug teen see sê die volkscliché/ sal ons eerder boere nie matrose eerder trekkers/ nie vertrekkers die laaste loopgraaf grawe ..."

\subsection{Boer (hoofletter)}

Die keuse vir die hoofletter by Boer impliseer op sigself ' $n$ keuse vir die gebruik van die woord as etnoniem. Soms word sommige van hierdie betekenisse oorgedra op boer en verkry ook dié woord 'n ideologiese lading. So is Afrikaans byvoorbeeld van vroeg af en tot in ons eie tyd gekoppel met boer, byvoorbeeld in "Di Afrikaanse taal": "Ek is ' $n$ arme boerenôi ..." (Afrikaanse Gedigte 1876-1906; Anon., 1987:12). Ronnie 
Belcher (1978) speel op ' $n$ ander bekende vroeë gedig in: "toe wil ek die here/ in die boeretaal prys / maar dis alles alles Ingels ..." (Komrij, 1999:653), maar dra dieselfde boodskap oor. André Letoit (1985:10) verwys in "Steunpilaar-suite" na "Moettaal, voertaal, boertaal, meisie ...".

Die etnoniem Boer, met sy ideologiese implikasies en noue verwantskap met die term Afrikaner, is (soos genoem) oorspronklik waarskynlik uit Engels afkomstig. Vanuit veral die Britse perspektief is sowel Boor as Boer aanvanklik neutraal gebruik, of met negatiewe konnotasies (soos boor). Die gebruik van Boor deur Britte in Suid-Afrika om Nederlandse boere te benoem, blyk byvoorbeeld uit die dagboek van Lady Anne Barnard 1799 (in Lenta \& Cordeur, 1999 Volume 1:72): "A large party of country gentlemen, viz Boors from the country ..." (asook 1999:232 en 237). In Volume 2 (30 Januarie 1800) word sterk negatiewe kenmerke met dié benaming verbind: "He describes the Boors to be of a most inhuman cruelty of nature, using my poor friends the Hottentots as ill as possible ..." (Lenta \& Cordeur, 1999:29).

Olive Schreiner (1923, in Schoeman, 1989:62-63) beskou ' $n$ insident waar sy as vierjarige (ongeveer 1852) ' $n$ handvol bruinsuiker laat val wat 'n boeredogtertjie aan haar gee ("To have eaten sugar that had been in the hand of a Boer child would have been absolutely impossible to me") as "in a way allegoric of the whole relation between the Anglo-Saxon and the Boer in South Africa" en praat van "anti-Dutch prejudices". Van die gedigte wat dr. Lydia van Niekerk (1920) aanhaal uit Di Patriot, soos ook die bloemlesing Afrikaanse Gedigte 1876 - 1906 laat blyk hoe bewus digters soos Oom Jan was van die feit dat die Britte die plaaslike bevolking as minderwaardig beskou het: "Dan kan jy met meer majesteit,/ Die domme boer vertrap in d' sand" lui die "Engelse Volkslied" (Van Niekerk, 1920:56). In "Di mislukte Jameson Komplot" (1906/ Anon., 1987:28-29) werk "Di Judasburgse fullisboel (...) al lank met duiwelslis/ en het di 'Boers' bespot".

Met die opbou van nasionalistiese (en taal)gevoelens tydens en na die Eerste en Tweede Vryheidsoorloë, het Boer egter soos 'n geusenaam 'n steeds meer positiewe lading verkry, ook in aansluiting by die sterk en wydverspreide heroies-nasionalistiese tendense wat die 19de eeu gekenmerk het. Die toename in die gebruiksfrekwensie van Boer in die letterkunde teen die einde van die 19de eeu blyk onder meer uit die geskrifte in Di Patriot en Ons Klyntji (vgl. Afrikaanse Gedigte 1906/ Anon., 1987:31, 34-45, 50, asook Van Niekerk, 1920:52, 58-64, 69).

Die hoofletter Boer word wel in die 19de eeu soms op nie-nasionalistiese wyse gebruik (kyk Komrij, 1999:54, 81 en Walters, 1986:42), maar die Anglo-Boereoorlog het die sterk mitologisering van Boer as etnoniem 
meegebring, nie alleen in Suid-Afrika nie, maar ook in Nederland en selfs in Brittanje. A. Conan Doyle (1900) beskryf die "modern Boer" byvoorbeeld as "the most formidable antagonist who ever crossed the path of Imperial Britain" (in Potgieter Deel 1, 1970:194). Vir Verwey was die Boer die nuwe mens, die laaste manifestasie van die lewenskrag in die evolusie (kyk Van Halsema, 1994b:390). Schutte (1986:24-98) gee 'n uitgebreide bespreking van die Nederlandse pro-Boer-beweging sedert 1880-1881 en die groot toename in belangstelling en betrekkinge veral tot in 1902. Ten spyte van 'n afname in belangstelling daarna, het ' $n$ gevoel van vereenselwiging voortgeduur tot en met Sharpeville in 1960. Hy beskryf hierdie ideologiese geladenheid van die Nederlandse proBoersimpatieë egter as "een gesublimeerde uitlaatklep voor allerlei gevoelens van angst en minderwaardigheid (..) ze vormde een ongevaarlijke mogelijkheid het 'perfide Albion' dwars te zetten" (Schutte, 1986:205). In die Afrikaanse letterkunde van na die Anglo-Boereoorlog tot in die vyftigerjare was Boer 'n oorheersend positiewe begrip, dikwels verbind met die - vergelyk die bekende "Maar een Suidafrika" deur A.D. Keet uit 1920: "Gee my 'n roer in my regterhand, I (...) En 'n Boerseun wat baie wa:/ Gee my Suidafrika (sic)" (Keet, 1925:83). Hierdie positiewe konnotasies is ook oorgedra op boer en het die gevoelens van vereenselwiging verder vergroot.

Tog kom die woord as heroïese etnoniem veel minder dikwels voor in die eerste gedigte oor die oorlog deur Totius, Celliers en Leipoldt as wat verwag sou word - selfs nie wanneer dit 'n voor die hand liggende rymkeuse is nie, soos in Celliers se "Veldbrand" (1908). In Martjie (1911) ontbreek dit heeltemal, selfs in die deel oor die oorlog, soos ook in Totius se By die monument (1908), in Oom Gert vertel en ander gedigte (1911) van Leipoldt en in Dingaansdag (1920). Moontlik is dit in die eerste jare na die Oorlog nog te sterk geassosieer met die negatiewe konnotasies wat oorheers het in die Britse reklameveldtog tydens die Oorlog. Celliers se "Japie Greyling" (1908) dui dalk hierop: na 'n verwysing na "Skandenaam van 'beedlaar-geus'/ word der vaadre ere-leus", volg: "Kinders van Suid-Afrika,/ trots mag ons ons naam reeds dra, $(\ldots) /$ erenaam van 'Takhaar-Boer'!" (Celliers, 1934:53).

Boer word geleidelik steeds sterker verbind met die hele Afrikanergeskiedenis, ook in die vroeg $19 \mathrm{de}$ eeu. Langenhoven plaas die Boer byvoorbeeld teenoor Dingaan in Eerste skoffies op die pad van SuidAfrika $(1921 / 1927: 80,87,89)$ en laat laasgenoemde die volgende profetiese stelling uiter: "Die Boer sal win of die swartman sal/ win. Die Boer se pad/ Is die swartman se pad, die pad van/ Suid-Afrika (...) Dis óns wat stry oor die heerskappy - die/ Engelsman staan opsy" (Langenhoven, 1927:87). I.D. du Plessis, in "Ballade van twee Boere" uit 1945, 
gebruik Boer vir die tydperk net na die moord op Piet Retief (in Nienaber, 1954:75).

Totius onderskei in Trekkerswee (1915) pertinent tussen die hoof- en kleinletter. Boer figureer twee keer, een keer binne neutraal/negatiewe konteks (teenoor die swart man) in Dina se "modesang" (Totius, 1965: 45). Die tweede keer is dit ideologies bepalend vir die boodskap wat dié epiese gedig wil oordra: "Die Boer moet Afrika regeer!" (Totius, 1965:55). Die woord boer kom (afsonderlik en as deel van 'n samestelling soos trekkersboer, boereplaas, boerehuis, boerbeskawing en boere-paradys) 23 keer in dié teks voor, telkens baie positief. In A.G. Visser se Gedigte (1925) word Boer vyf keer (telkens positief) gebruik (byvoorbeeld "... land van die Boer" - Visser, 1981:88) en boer twee keer. In "Ruiters van die nag" (Visser, 1932:52) word nog na die Voortrekkers verwys as boere: "En die boerseun word 'n held" (strofe 4) en na die burgers in die Oorlog met 'n hoofletter: ("... de Boer se pompom" - strofe 13), maar dit is duidelik dat albei as etnonieme gebruik word. Du Pisani (1999:91) dui tereg op die "potensiaal van die Boerekrygerbeeld vir politieke mobilisering", wat benut is deur Afrikanernasionalistiese leiers:

Indien die beeld van die lydende Boerevrou in die konsentrasiekamp onder Afrikaners die mees emosioneel gelade anti-Britse metafoor was, dan was die beeld van die Boere-kryger as vryheidsvegter die mees nasionalistiese.

Die Afrikaanse poësie het ' $n$ groot rol gespeel om hierdie metafore by die volk in te skerp.

Hoe sterk die Boer in hierdie periode gemitologiseer is, blyk by uitstek uit N.P. van Wyk Louw (1939:36) se uitspraak:

Die 'Boer' soos hy in die werk van Celliers, Totius, Langenhoven, e.a. verskyn, is geen realistiese figuur nie, maar juis so ' $n$ menslike ideaal. Dit is die volledige uitdrukking van 'n politieke, godsdienstige en kulturele lewensbeskouing; dit was die beeld van die volk se strewe, 'n politieke vaandel in die swaar jare ná die oorlog en ná die opstand.

Hy bepleit vervolgens eerder 'n "hiërargie van gestaltes", want: "Die 'Boer' druk nie meer ons nasionale strewes volledig uit nie". Tog is dit so 'n kragtige metafoor dat dit tot in die sewentigerjare en later nog in gedigte voorkom, soos in "Ode" (1974) deur Johan de Jager, waar hy homself met die woorde "Ek is 'n Boer ..." (Komrij, 1999:716), egter veral met Afrika vereenselwig. 
Sommige van die eerste tekens van 'n ander optiek teenoor die Boer kom weer voor in P.J. Philander se Uurglas (1955/1956'254): "Toe het die Boere-oorlog die land vervloek ..." 'n bundel waarin die Ander begin terugskryf (soos ook S.V. Petersen met Die Enkeling, 1944, waarin boer/Boer ontbreek maar kontraste soos slaaf/heer voorkom). Philander (1982:47) volg dit later op met wrang-humoristiese observasies in onder meer "Boeretroos: Tevergeefs dat jy vir suiker roer,/ al wat jy kry is bitter moer" in die afdeling "Boerebedrog", en in "Boeta Boer" (Ostrakon 1986): "In hierdie stryd teen jou, boeta Boer,/ laat ons geen klip onaangeroer". Adam Small (1963:46) se "Boeresports" hekel in die sestigerjare die argeloosheid van die boere: "Terwyl God se hand/ met Armagéddon in die Suidoos vat,/ trek die boere by Melkbosstrand/ vinger en skilpad." Hier word boer duidelik ook as etnoniem gebruik.

Sedert die sestigerjare blyk die ontmitologisering van die Boer ook uit dramas soos N.P. van Wyk Louw se Die pluimsaad waai ver (1966, gepubliseer in 1972) en romans soos Etienne Leroux se Sewe dae by die Silbersteins (1962) en Magersfontein, o Magersfontein (1976), asook Op soek na generaal Mannetjies Mentz deur Christoffel Coetzee (1998).

Digters soos S.J. Pretorius, in sy "Die stoere Boere", uit: "Plaas-like figure" (1976:111); George Weideman ("en die jakkalsies boer in Boer se wingerd") in "Sondag, 10 Oktober 1976, Kaapstad" (Komrij, 1999:851) en André Letoit (1988:81) met sy "Ondergronds is God die hel in/ vir die Boerenasie" in sy gedig "Swart Transvaal", sit hierdie tendens op satiriese wyse in die poësie voort. Breyten Breytenbach verbind die Afrikaner in "16 Maart 1974" (in Coetzee, 1995:295) met die Boer: "(wat is 'n Afkaner?) ... (is dit ' $n$ boersjwa-Boer?)", dieselfde woordspel as wat André Letoit (1985:30) benut in "Die geel kafee": "Ons is die linksgesinde Boer-zjwasié". Boer en Afrikaner ontgeld dit eweneens in die volgende versreëls uit Saturae (1979) van M.M. Walters: “... hoe Boer se kind politieke mag verkry het" ("Generaal Piet", 1979:4), asook: "Die Boerekerk is aan die kwyn" en "... die Kerk van die Boere" in "Die Kerkbode berig Die Burger ..." (1979:10). Prevot van der Merwe, in "Kombuistaal" (1990:28), rig hom veral tot 'n nuwe groep wat Afrikaans misken: "baie kollegas op Bush/ maak die kinders op Engels groot/ dink so bôl mens die Boere/ en kierang apartheid dood".

\subsection{Bykomende betekenisse}

Hierdie gedigte beweeg reeds na aan die addisionele betekenisse van sowel Boer as boer wat in sommige Afrikaanse gedigte voorkom (vgl. A Dictionary of South African English). In "Ekkedemiek Boykot" deur Chris Ferndale (in Coetzee \& Willemse, 1989:77-78) word boere byvoorbeeld eers verbind met die polisie of weermag ("terwyl die boere/ met teargas/ 
en net sulke ysters/ vir ons deur die townships rushs (sic.)" en later met die Afrikaner in die algemeen. Ook Breytenbach (1993, in Coetzee, 1995:304 en 307) praat van Boere en boere in hierdie sin: "en hoor Here die geloei van die Boere se vangwaens" (in "Hoor, Here") en "... Botha se troepe boer en pandoer" (in "betekenis en woordbetekenis. Vir Hector Petersen, 16 Junie 1976"). Hier word dit steeds as pejoratiewe etnoniem gebruik.

In André Letoit se "bespreking oor Van Gogh en dooie voëls" (1985:12) het boere egter nie met een van Van Dale se betekenisonderskeidings te doen nie, maar eerder met die WAT se betekenis van "maats": "hoë woorde is nie vir ons boere nie/ nogtans verstaan ons die stilte van baie stemme". Dit sluit aan by Du Pisani (1999:108) se slotbevinding dat "baie van die jong geslag alternatiewe Afrikaners hulle nie van die benaming 'Boer' distansieer nie" - iets wat hy verbind met 'n "hertoe-eiening van die destydse eretitel 'Boer' om van die gestigmatiseerde 'Afrikaner' weg te kom", maar dit is myns insiens 'n oorvereenvoudiging. Die satiriese blik op boer en Boer die afgelope dekades in die poësie wys eerder op wisselende afstand en vereenselwiging, dieselfde kenmerke wat van vroegs af inherent was aan die terme Boer/boer. Dit kan wel daarop dui dat die begrippe nie noodwendig as nasionalistiese etnonieme gebruik word nie, maar in die poësie bied juis die ambivalensie van Boer en boer steeds ryke stof.

\section{Gevolgtrekking}

Die verskillende woordeboekbetekenisse van Boer en boer word goed geïllustreer in die Afrikaanse poësietekste van die afgelope ongeveer 125 jaar, wat telkens eweneens 'n tyds- en konvensiegebonde konstruksie gee van boer en Boer, vanuit 'n positiewe, neutrale of negatiewe optiek, in samehang met die sosiaal-politieke konteks. Veral die etnoniem Boer, wat as Afrikaner-geusenaam aangegryp is binne die opkomende taalnasionalistiese en nasionalistiese Eerste Taalbeweging, asook die Eerste en Tweede Vryheidsoorloë (ook in pas met breë 19deeeuse tendense), het in die Afrikaanse poësie 'n pad geloop wat sterk afwyk van dié in die Nederlandse tekste (met uitsondering van 'n kort "oplewing" van entoesiasme vir die Boer tydens die Anglo-Boereoorlog). $\mathrm{Na}$ ' $\mathrm{n}$ veelseggende stilte/afwesigheid in die Afrikaanse poësie van net na die Anglo-Boereoorlog, het Boer dawerend teruggekeer en is toegepas op die hele Afrikanergeskiedenis.

Reeds in die vyftigerjare kry Boer en boer egter ' $n$ magsgekoppelde negatiewe assosiasie as die Ander begin terugskryf. 'n Ontwikkeling kan dus bespeur word van (Britse) negatiwiteit teenoor die Boer as die Ander, na positiewe Afrikaner-selfdunk, na hernude negatiwiteit teenoor 
Boer as magshebber. Daarnaas het die materiële welvaart van die sestiger- en begin-sewentigerjare neerslag gevind in satiriese kommentaar op boere wie se lewenstyl en bedrywighede ingegaan het teen die konvensionele verwagtinge van soberheid, hardwerkendheid en nederigheid. In die eietydse Afrikaanse poësie word steeds ingespeel op die volle spektrum van betekenisse gekoppel aan sowel boer as Boer, maar die ironie en satire waarmee dit dikwels gepaardgaan, laat blyk dat die tyd van hoë nasionalistiese vlugte voorlopig verby is en dat ontmitologisering (weer in aansluiting by ruimer tendense) aan die orde van die dag is.

'n Enkele kernwoord kan dus, soos hier geillustreer, 'n rykdom van betekenisse ontsluit deur binne verskillende kontekste te skakel met uiteenlopende geskiedenisse, as deel van verskillende argumentasiekettings (Engbersen \& Jansen). "Die seleksie in 'n gedig van byvoorbeeld Boer in plaas van die meer neutrale boer, dui terselfdertyd op 'n keuse vir 'n soort representasie, 'n soort kulturele diskoers" (Said, 1978:21) wat, indien dit in meer gedigte voorkom, uiteindelik die voorkoms van 'n letterkunde in 'n sekere tydvak kan bepaal.

\section{Bibliografie}

A Dictionary of South African English. New enlarged edition. 1980. Kaapstad : Oxford University Press.

Anon. (Du Toit, S.J.). 1987 (1906). Afrikaanse Gedigte. Byeenfersameld uit wat in di laaste 30 jaar ferskyn is 1876-1906. Verkleinde faksimileeherdruk. Met 'n nuwe inleiding deur prof R.H. Pheiffer en registers Kaapstad : Suid-Afrikaanse Biblioteek.

Antonissen, Rob (samest) 1986. Digkuns van die Nederlande 1100-1970. Deel 1. Stellenbosch: UUB.

Bakker, Siem (red ) $1994^{2}$ (1992). Nieuwe Literatuurgeschiedenis. Overzicht van de Europese letteren van Homerus tot heden. Deel III. Amsterdam : Meulenhoff Ilcarus.

Blanckenberg, N.A. (vertaler). 1975. Vergilius. Landelike poësie, Bucolica, Georgica. Pretoria : HAUM.

Blum, Peter. $1963^{3}$. Steenbok tot Poolsee. Kaapstad : Nasionale Boekhandel.

Boehmer, Elleke. 1995. Colonial \& Postcolonial Literature. Oxford : Oxford University Press.

Borgers, Gerrit (samest). 1974 ${ }^{5}$. Music-Hall. Een programma vol charlestons, grotesken, polonaises en dressuurnummers van Paul van Ostaijen. Den Haag Bakker.

Breytenbach, Breyten. 1967. Die huis van die dowe Kaapstad: Human \& Rousseau Breytenbach, Breyten. 1976 ${ }^{2}$. Skryt. Om 'n sinkende skip blou te verf. Amsterdam : Meulenhof.

Cambridge International Dictionary of English. $1996^{3}$. Cambridge : Cambridge University Press.

Celliers, Jan F.E. $1934^{9}$ (1908). Die vlakte en ander gedigte. Kaapstad: Nasionale Pers.

Celliers, Jan F.E. 195922 (1911). Martjie. Kaapstad : Nasionale Boekhandel 
Claus, Hugo. 1982. Almanak. Amsterdam : Bezige Bij.

Claus, Hugo. 1994. De sporen. Amsterdam : Bezige Bij.

Coetzee, Ampie \& Willemse, Hein. 1989. I Quabane Labantu. Poësie in die noodtoestand. Bramley : Taurus.

Coetzee, Ampie (samest). 1995. Die hand vol vere. ' $n$ Bloemlesing uit die poësie van Breyten Breytenbach. Kaapstad: Human \& Rousseau.

Coetzee, Ampie. 1999. 'n Hele os vir 'n ou broodmes. Grond en die plaasnarratief sedert 1595. Pretoria \& Kaapstad: Van Schaik \& Human \& Rousseau.

Collins Cobuild English Language Dictionary. $1990^{5}$. London: William Collins.

De Balker, Habakuk II. 1974. Boerengedichten. Uier van 't oosten. Amsterdam : De Bezige Bij.

De Vries, Anne. 1998. Van catechismus tot idylle. Noordzee, Taal \& Letteren, 1(1):34-35.

De Vries, Willemien. 1998. Dichters tussen stad en land. Noordzee, Taal \& Letteren, 1(1):32-33.

Dierdicht en geestelijke epiek. Van den vos Reynaerde. Esopet. De reis van Sente Brandane. Beatrijs. 1984. Prisma Pocket. Utrecht : Het Spectrum.

Du Pisani, Kobus. 1999. "Volkshelde": Die Boerekrygerbeeld en die konstruksie van Afrikanernasionalisme. Literator, 20(3):87-111.

Engbersen, Radboud \& Jansen, Thijs. 1991. Armoede in de maatschappelijke verbeelding (1945-1990). Een retorische studie. Leiden : Stenfert Kroese.

Etimologisch Woordenboek. 1989. Utrecht : Van Dale Lexicografie.

Grünthal, Riho. 1997. http://www.helsinki.fi/jari/sus/ct51grunthal.html (Geraadpleeg op 27 Oktober 2000.)

Hanlo, Jan. 1970. Verzamelde gedichten. Amsterdam : Van Oorschot

Hugo, Daniel (samest.) 1988. Speelse verse Kaapstad: Tafelberg.

Janssens, Marcel. 1994. Met groter L. Van Couperus tot Claus. Leuven : Davidsfonds/Clauwaert.

Kannemeyer, J.C. 1978. Geskiedenis van die Afrikaanse literatuur. Deel 1. Kaapstad : Academica

Keet, A.D. $1925^{4}$. Gedigte. Amsterdam : Swets \& Zeitlinger.

Komrij, Gerrit (samest.) 1999. De Afrikaanse poëzie in duizend en enige gedichten Amsterdam : Bert Bakker

Kopland, Rutger. 2000 ${ }^{3}$. Gedichten 1966-1999. Amsterdam : Van Oorschot.

Krog, Antjie. 1985. Jerusalemgangers. Kaapstad : Human \& Rousseau.

Langenhoven, C.J. $1927^{3}$ (1921). Eerste skoffies op die pad van Suid-Afrika. Kaapstad: Nationale Pers.

Leipoldt, C. Louis. $1921^{3}$ (1911). Oom Gert vertel en ander gedigte. Pretoria : De Bussy.

Leipoldt, C Louis $1925^{2}$ (1920). Dingaansdag. Pretoria : Van Schaik

Lenta, Margaret \& Le Cordeur, Basil. 1999. The Cape Diaries of Lady Anne Barnard 1799 - 1800. Kaapstad : Van Riebeeck Vereniging.

Letoit, André. 1985. Die geel kafee. Kaapstad: Perskor

Letoit, André. 1988. Die bar op De Aar. Ballades, blues en bevliegings. Kaapstad Tafelberg.

Longman Dictionary of Contemporary English. $1990^{11}$. Essex : Longman

Louw, N.P. van Wyk. 1939. Berigte te velde. Opstelle oor die idee van 'n Afrikaanse nasionale letterkunde. Pretoria: Van Schaik.

Louw, N.P. van Wyk. $1963^{2}$. Tristia. Kaapstad: Human \& Rousseau

Louw, W.E.G. $1961^{7}$. Die ryke dwaas. Kaapstad: Nasionale Boekhandel.

Louw, W.E.G. 1988. Versamelde gedigte. Kaapstad: Tafelberg. 
Middelnederlandsch Handwoordenboek. 1976. 's-Gravenhage : Martinus Nijhoff.

New Collegiate Dictionary. 1979. Springfield, Mass. : Merriam.

Nienaber, G.S. 1942. Afrikaans tot 1860. Johannesburg : Voortrekkerpers.

Nienaber, P.J. $1954^{3}$. Digters en digkuns. Johannesburg : APB.

Opperman, D.J. $1947^{2}$. Heilige beeste. Kaapstad : Nasionale Pers

Opperman, D.J. $1967^{4}$. Negester oor Ninevé. Kaapstad: Nasionale Boekhandel.

Petersen, S.V. 1944. Die enkeling. Port Elizabeth : Unie-Volkspers.

Philander, P.J. 1956². Uurglas. Kaapstad: Nasionale Boekhandel.

Philander, P.J 1982. Venster. Johannesburg : Perskor

Philander, P.J. 1996. 'n Keur uit sy gedigte. Samest. Daniel Hugo. Kaapstad/ Midrand : Tafelberg/Perskor.

Pienaar, P. de V. 1968. Kultuurgeskiedenis van die Afrikaner. Kaapstad : Nasionale Boekhandel

Potgieter, D.J. (red.) 1970. Standard Encyclopedia of Southern Africa. Deel 1. Kaapstad : Nasou.

Pretorius, S.J. 1976. Album. 'n Keur uit sy gedigte. Kaapstad: Human \& Rousseau.

Reitz, F.W. $1916^{5}$ (1909). Twee en sestig uitgesogte Afrikaanse gedigte. Kaapstad HAUM

Riggs, Fred W. 1999. Intercocta Glossary. Concepts and terms used in ethnicity research. http://uww2hawaii.edu/ fredr/6-int6a htm (Geraadpleeg op 27 Oktober 2000.)

Said, Edward W. 1978. Orientalism. Harmondsworth : Penguin

Schoeman, Karel. 1989. Olive Schreiner, 'n lewe in Suid-Afrika 1855-1881. Kaapstad: Human \& Rousseau

Schutte, G.J. 1986. Nederland en de Afrikaners: adhesie en aversie: over stamverwantschap, Boerenvrienden, Hollanderhaat, Calvinisme en apartheid. Franeker: Wever.

Small, Adam. 1963. Sẻ Sjibbolet. Johannesburg : Perskor.

Steyn, J.C. 1975. Die grammatika van liefhê. Kaapstad: Tafelberg

Stuiveling, G. (red.) 1975. G.A. Bredero's Boertigh, Amoreus, en Aendachtigh Groot Lied-Boeck. Culemborg: Tjeenk Willink

The Concise Oxford Dictionary of current English. $1944^{3}$. Adapted by H.W. Fowler \& F.G. Fowler from The Oxford Dictionary. Oxford : Clarendon.

The Oxford English Dictionary. $1989^{2}$. Volume 2. Oxford : Clarendon.

Timmermans, Lieke. 1996. De wereld volgens C.M. van den Heever. Leiden Rijksuniversiteit. (Ongepubliseerde doctoraalscriptie.)

Totius. $1917^{5}(1908)$. By die monument. Bloemfontein : Nasionale Pers.

Totius. $1965^{19}(1915)$. Trekkerswee. Kaapstad : Nasionale Boekhandel.

Vaartjes, Gé. 1998. De aarzelende herwaardering van streekliteratuur. Noordzee, Taal \& Letteren, 1(1):42-44

Van den Heever, C.M. (red.) 1934. Die landelike lewe in die romankuns. Die Vaderland, Jan. 26.

Van Dale Etymologisch Woordenboek. 1989. Utrecht : Van Dale Lexicografie.

Van Dale. Groot Woordenboek der Nederlandse Taal. 1984". Utrecht : Van Dale Lexicografie.

Van der Merwe, Prevot. 1990. Boerejive. Kaapstad : Human \& Rousseau.

Van Coller, J.P. 1995. Die Afrikaanse plaasroman as ideologiese refleksievan die politieke en sosiale werklikheid in Suid-Afrika. Stilet, VII(2):22-31

Van Gorp, H. e.a. 19934. Lexicon van literaire termen. Groningen : WoltersNoordhoff. 
Van Halsema, J.D.F. 1994a. Te zoeken in deze angstige eeuw. Sporen van décadence-voorstellinge in de Nederlandse letterkunde aan het einde van de negentiende eeuw. Groningen : Historische Uitgeverij.

Van Halsema, D. 1994b. In verwachting van de nieuwste mens: Nederlandse literatoren rond 1900 over Zuid-Afrika. In: Hatting, Marion \& Willemse, Hein. Vernuwing in die Afrikaanse letterkunde. Bellville: UWK-Drukkery. p. 381-392.

Van Heerden, Etienne. 1987. Die laaste kreef. Kaapstad : Tafelberg.

Van Niekerk, Lydia. $1920^{2}$. De Eerste Afrikaanse Taalbeweging en Letterkundige Voortbrengselen. Kaapstad: Nationale Pers.

Van Niekerk, Marlene. 1977. Sprokke/ster. Kaapstad : Human \& Rousseau.

Van Vliet, Eddy (samest.) 1998. Tussen droom en daad. De 200 bekendste gedichten uit de Vlaamse poëzie van de Middeleeuwen tot nu. Gent: Poëziecentrum.

Van Zyl, Wium. 1995. 'n Groene in De Nieuwe Gids, Frederik van Eeden, De kleine Johannes en die ekologisme. Literator, 16(2):123-136.

Visser, A.G. $1932^{8}$. Gedigte. Pretoria : Van Schaik.

Visser, A.G. 1981. Versamelde gedigte. Versorg en ingelei deur Merwe Scholtz. Kaapstad : Tafelberg.

Walters, M.M. 1967. Cabala Kaapstad : Nasionale Boekhandel.

Walters, M.M. 1974. Heimdall. Kaapstad : Tafelberg.

Walters, M.M. 1979. Saturae. Kaapstad : Tafelberg.

Walters, M.M. (samest.) 1986. Die tiende muse. Afrikaanse satires. Kaapstad Perskor.

Wasserman, Herman. 1997. Die Stoetmeester deur Etienne van Heerden binne die plaasromantradisie in Afrikaans. Stellenbosch : US. (M.A.-verhandeling.)

Watermeyer, G.A. 1948. Sekel en simbaal. Kaapstad : Nasionale Boekhandel.

Webster's New International Dictionary ${ }^{2}$. 1948. Springfield, Mass. : Merriam.

Woordeboek van die Afrikaanse taal. 1950. Pretoria : Staatsdrukker.

\section{Kernwoorde:}

boer en Boer: wisselende betekenisse

sosiaal-politieke konteks: Afrikaanse poësie veranderende optiek

\section{Key concepts:}

boer and Boer: changing meanings

changing perspectives

social-political context: Afrikaans poetry 
